\title{
7. Non-food and non-housing costs
}

\section{PART I. BACKGROUND}

\subsection{Introduction and Use of Secondary Data with Primary Data Post Checks}

This chapter describes how to estimate the cost of all essential needs for decency besides food and housing. In our methodology, a preliminary estimate of non-food and non-housing (NFNH) costs is made using recent household expenditure survey data by multiplying the NFNH to Food expenditure ratio in these data by the cost of the living wage model diet. This yields a preliminary estimate of NFNH costs. Subsequently, post checks of the preliminary estimate of NFNH costs are done using primary data collected in the study location to help ensure that a living wage estimate is more normatively based and there are sufficient funds for health care and education which are considered human rights around the world. ${ }^{1}$ Our approach is a practical compromise between the impractical approach of identifying and estimating the cost of each and every NFNH need of workers and families, and the conceptually problematic approach of most other living wage and poverty line methodologies for developing countries that uncritically use the current spending of households indicated by a recent household expenditure survey to measure all non-food needs. The latter approach is especially problematic in poor countries where many households at present have little left over to spend on NFNH needs.

\subsection{What are NFNH Costs?}

Countries differ in how they measure and classify NFNH expenditure. It is important for researchers to examine the national classification of household expenditures, and to adjust secondary household expenditure data to make them consistent with how food, housing, and NFNH are measured in our living wage methodology. This also increases cross-national comparability of living wage estimates.

Most, but far from all, countries use the internationally accepted classification for household expenditures COICOP (Classification of Individual 
Consumption According to Purpose) or a similar classification for household expenditures collected from household budget or expenditure surveys. First-level expenditure groups in COICOP are listed below with an indication in brackets as to which of our three expenditure groups they belong: food, housing, NFNH. See Appendix 7.1 for a more detailed listing of COICOP, and Appendix II in ILO et al. (2004) for a highly detailed listing and description.

- Food and non-alcoholic beverages (Food)

- Alcoholic beverages, tobacco and narcotics (alcohol in NFNH; tobacco and narcotics excluded)

- Clothing and footwear (NFNH)

- Housing, water, electricity, gas and other fuels (Housing)

- Furnishings, household equipment and routine household maintenance (NFNH)

- Health (NFNH with post check)

- Transport (NFNH with possible post check)

- Communication (NFNH)

- Recreation and culture (NFNH)

- Education (NFNH with post check)

- Restaurants and hotels (part in Food and part in NFNH)

- Miscellaneous goods and services (NFNH)

\subsection{Variability in How Countries Measure and Classify Food, Housing, and NFNH in Household Expenditure Statistics}

Although COICOP forms the basis for most national classifications of household expenditures, many countries do not use COICOP. Many countries use an earlier version of COICOP, and many other countries that use the latest COICOP structure make adjustments. ${ }^{2}$ It is therefore important for researchers to look closely at how national household expenditures are measured and classified, and then adjust reported household expenditure data to be consistent with our living wage methodology. Some common differences between classifications used by countries and the latest COICOP particularly relevant for our living wage methodology include the following. These are discussed in greater detail in Part II of this chapter.

- Alcohol and tobacco are often included in the food group in national household expenditure classifications because this is where they were included in previous versions of COICOP ${ }^{3}$ The food expenditure share in such data needs to be reduced, because alcohol and tobacco are not included in a living wage model diet in our methodology. In 
our methodology alcohol is included in NFNH expenditures and tobacco is excluded from expenditures altogether.

- Food eaten away from home is often included in the food group in national classifications even though food eaten away from home is treated as a separate expenditure group in COICOP. ${ }^{4}$ This happens more frequently in countries where eating out is common such as in South-East Asia, East Asia, the United States, and parts of Latin America and Europe. When eating away from home is included in the food expenditure group, the percentage for food found in national statistics needs to be reduced by the portion of the cost of meals away from home for services and profit (e.g. food preparation, cooking, serving, and cleaning), and NFNH increased accordingly.

- When food eaten away from home is included in its own separate expenditure group as in COICOP, percentage for food needs to be increased by that portion of the cost of meals away from home for the food in these meals, with NFNH decreased accordingly.

- Anomalies are common in how countries classify household expenditure. Some anomalies affect NFNH estimates in our methodology. For example, Vietnam includes cooking fuel in the food expenditure group. This inflates the size of the food expenditure group, and therefore requires an adjustment in our methodology. Kenya includes only medicines in the health care expenditure group. This means that how much Kenyan households actually spend on health care is understated in Kenyan expenditure statistics. Existence of such anomalies in national statistics is one reason why post checks are done for health care, education, and sometimes transport in our methodology.

- There is considerable variation in how national statistical offices treat owner-occupied housing. Many (e.g. close to half of European countries) ignore owner-occupied housing, giving it zero cost in their household expenditure statistics. India ignores the cost of owner-occupied housing in rural areas only. Although in our methodology there is no need to make adjustments when owner-occupied housing is ignored in national statistics because we estimate housing costs separately based on a local market survey, this variability has a major effect on the estimate of non-food costs in other common living wage and poverty line methodologies for developing countries that estimate non-food costs in one go. For example, non-food costs would be underestimated by other methodologies in Vietnam where the cost and user value of owner-occupied housing are ignored in household expenditure statistics as only $4.7 \%$ of rural household expenditure and $7.4 \%$ of urban household expenditure is reported 
to be for housing (for utilities) according to household expenditure data (Table 7.4). In Shanghai, a very expensive city, only $8 \%$ of household spending is reported to be for housing excluding utilities according to household expenditure data.

\section{PART II. ESTIMATING NFNH COSTS FOR A LIVING WAGE: CONCEPTUAL AND EMPIRICAL ISSUES}

Part II discusses conceptual and empirical issues that affect how non-food and non-housing (NFNH) costs are estimated in our methodology.

\subsection{Different Approach Used to Estimate NFNH Costs than Used to Estimate Food and Housing Costs}

NFNH costs are estimated by multiplying the NFNH to Food ratio based on secondary data by the cost of the model diet and possibly adjusting this preliminary NFNH estimate by post checks based on primary and secondary data:

$N F N H=(N F N H / F o o d$ ratio from secondary data $\times$ living wage model diet cost $)+$ possible post checks adjustments for health care and education and transport

This approach is conceptually different from the way that food and housing costs are estimated in our methodology.

1. Food and housing cost are estimated based on normative standards (nutritious diet and healthy housing standard). NFNH costs are based to a large extent on household expenditure survey data that reflect current spending. This approach is used for practical reasons because it would be too time-consuming and difficult to agree on quantity and quality standards for the wide range of NFNH needs. Note that use of an 'other expenses' group is common to almost all poverty line and living wage methodologies, ${ }^{5}$ and that the 'other' expense group (NFNH) in our methodology is much smaller than the 'other' expense group (non-food) in other methodologies used in developing countries.

2. Post checks to the preliminary estimate of NFNH costs are done for health care and education to make sure that a living wage includes sufficient funds for these to increase the normative basis for NFNH because health care and education are considered human rights around the world. A post check is recommended for transport in 
locations where this is an important expense, and food, housing, health care and education expenditures taken together are less than around $60-70 \%$ of all spending. This helps ensure that the size of the non-normatively based NFNH is not too large.

\subsection{NFNH Costs and NFNH to Food Ratio Increase with Household Income and Economic Development}

The NFNH to Food ratio increases with household income and economic development. This is because the income elasticity ${ }^{6}$ of food expenditure is well below 1.0 as predicted by Engel's law ${ }^{7}$ (Anker, 2011a) and the income elasticity of housing expenditure is only slightly above 1.0 (around 1.2 according to Seale and Regmi, 2006). ${ }^{8}$ This means both that the food share of household expenditure should decrease with household income and the NFNH to Food ratio should increase with household income. This also means that the NFNH to Food ratio should usually be higher in urban areas compared to rural areas within countries, because urban areas tend to have higher income.

\subsubsection{Food share falls with economic development}

Table 7.1 and Figure 7.1 indicate the relationship between food share of household expenditure and income per capita for 207 countries and territories. Food share falls on average from $48 \%$ in low income countries to $15 \%$ in high income countries with the non-food to food ratio increasing on average from 1.08 to 5.67 (Table 7.1). Figure 7.1 shows that this relationship is non-linear. It is clear that Engel's Law, formulated in 1857, is still relevant in the twenty-first century (Anker, 2011a). At the same

\section{Table 7.1 Average percentage food and non-food to food ratio by development level}

\begin{tabular}{lcc}
\hline Development level $^{\mathrm{a}}$ & Percentage food $^{\mathrm{b}}$ & Non-food to food ratio $^{-}$ \\
\hline Low income & 48 & 1.08 \\
Lower middle income & 37 & 1.70 \\
Upper middle income & 29 & 2.45 \\
High income & 15 & 5.67 \\
\hline
\end{tabular}

Notes:

a Countries were equally divided into four groups based on income per capita in PPP.

b Values based on a regression with per capita income percentage urban, income inequality, whether country was transition economy country, and if country was island state.

Source: Anker (2011a). 


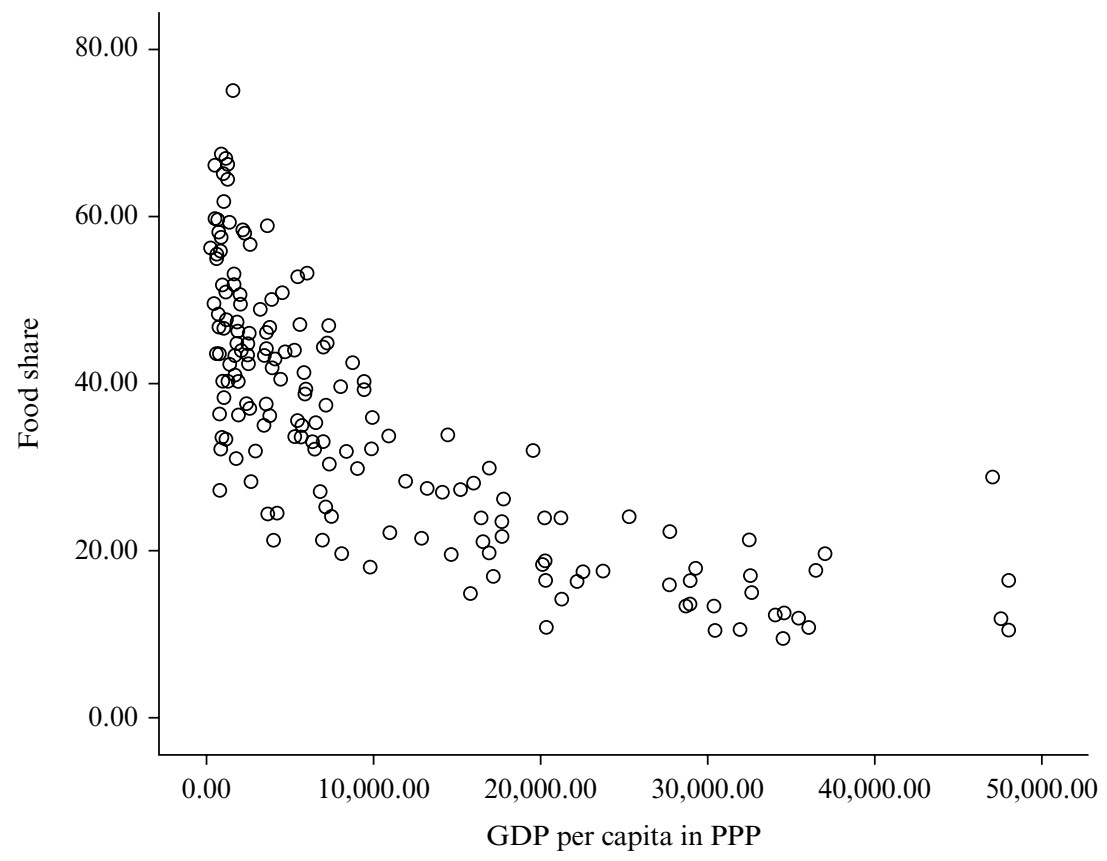

Source: Anker, 2011.

Figure 7.1 Food share of household expenditure as a function of income per capita in PPP (purchasing power parity), 207 countries or territories

time, since there are substantial differences in food shares for countries at similar per capita incomes, it is also clear that one needs to be cautious about using food share as the sole basis for estimating non-food costs as is done in other common methodologies for developing countries. Part of the reason for so much variability between food shares for countries with similar per capita incomes is measurement differences (e.g. data are sometimes only for urban areas; alcohol, tobacco, and eating away from home are sometimes included in the food expenditure group; cost or value of owner-occupied housing is ignored in some countries). Food share is also systematically different in certain types of countries (transition economy countries and island states have different food shares ceteris paribus) as well as significantly affected by household income inequality in a country (Anker, 2011a).

Figure 7.2 illustrates that the negative relationship between food share and per capita income found in the cross-national analysis in Figure 7.1 


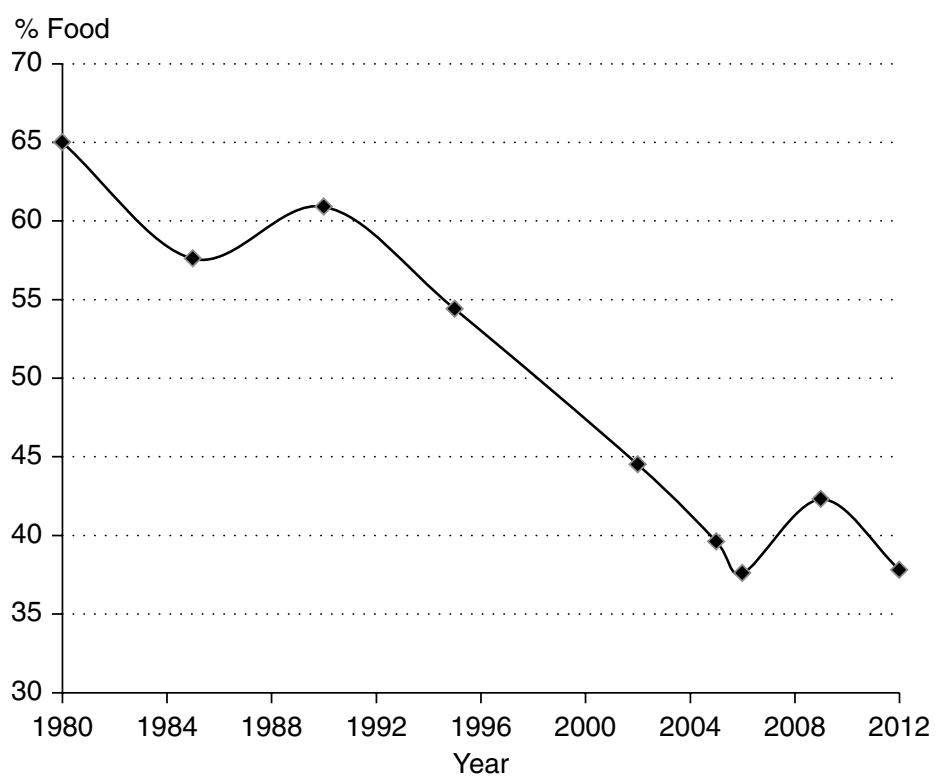

Notes: Real GDP per capita was 3.5 times higher in 2012 than in 1980.

Source: Government of Sri Lanka, 2015 (Table H1).

Figure 7.2 Falling food share of household expenditures in Sri Lanka, 1980-2012

is also found over time in countries such as Sri Lanka with increasing per capita income. Notice, however, that food share does not continuously fall every year probably due to short-term spikes in food prices in some years.

\subsubsection{Food share falls and NFNH to food ratio increases with household income within countries}

Table 7.2 provides information for five developing countries on how expenditure shares for food, housing, and NFNH and the NFNH to Food ratio differ with household income. The NFNH share and the NFNH to Food ratio both increase with income in all five countries and they are higher based on average (mean) expenditure (which is greatly influenced by spending of richer households) than for the median household. This means that:

- NFNH to Food ratio is affected by which part of the income distribution is used to measure it. 


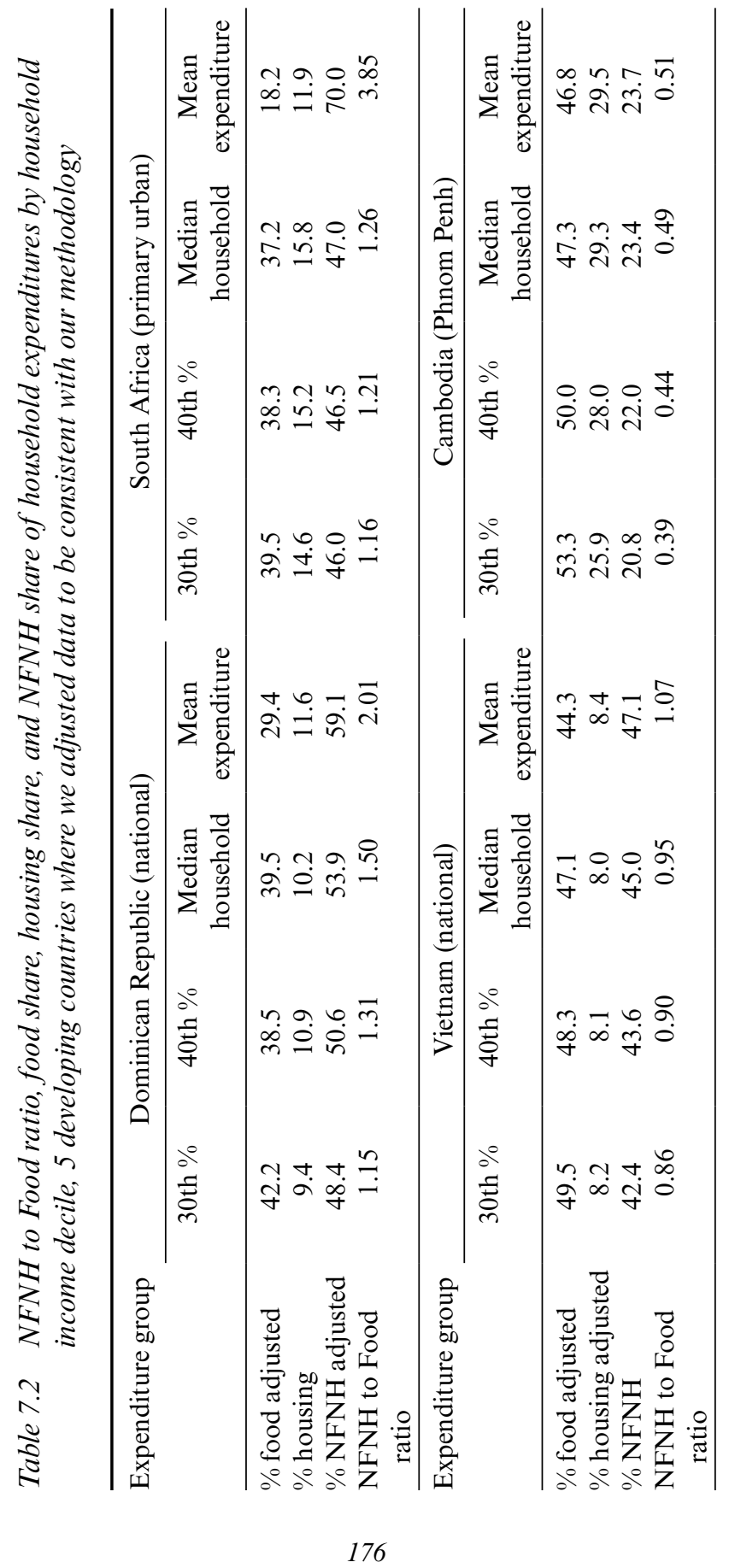




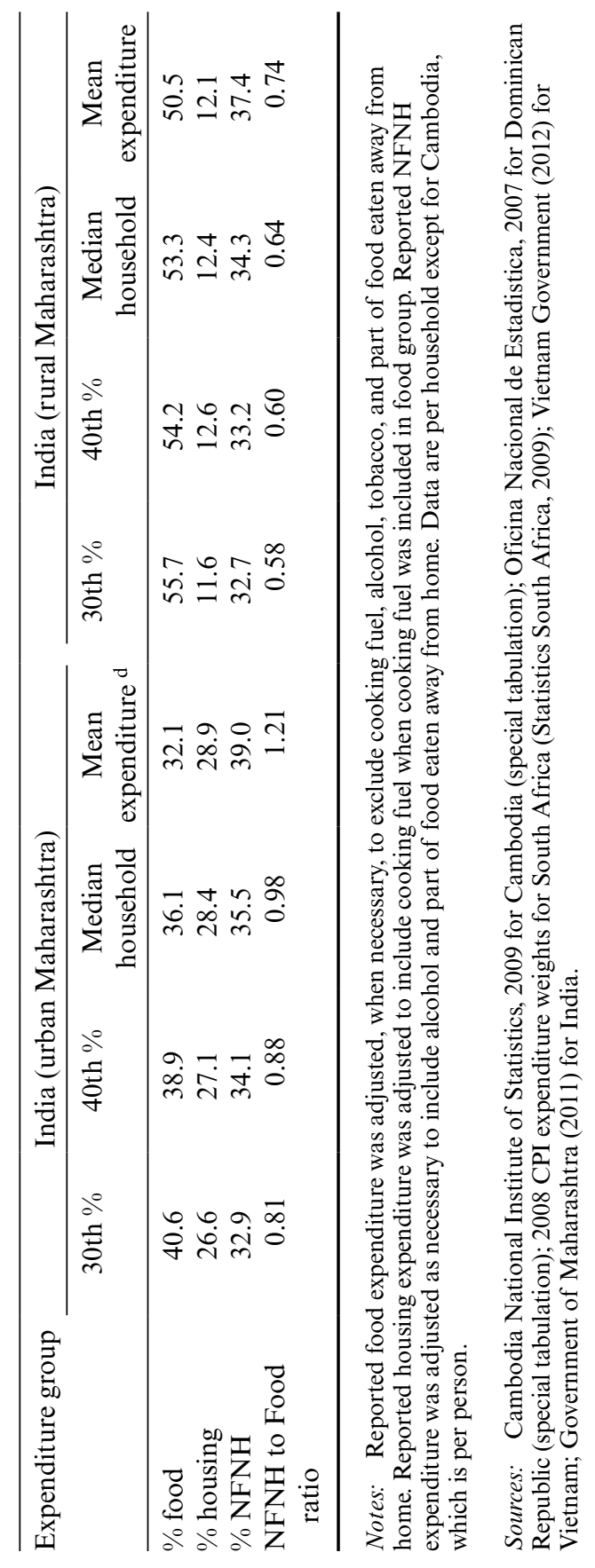


- NFNH to Food ratio is lower in these five countries on average by around $7 \%$ for the 40 th percentile household compared with the median household, and lower by around another $7 \%$ on average for the 30 th percentile household compared with the 40th percentile household.

- Differences between the NFNH to Food ratios for the 30th to 50th percentile of the expenditure distribution are almost always smaller than the difference between the NFNH to Food ratio for the median household and average (mean) expenditure.

- Differences in the NFNH to Food ratio for households at the 30th to 50 th percentile of the expenditure distribution are generally not very sensitive to the level of income inequality in a country.

\subsection{NFNH Costs and NFNH to Food Ratios Differ in Rural and Urban Areas}

Expenditure patterns are generally quite different in rural and urban areas. Expenditures for housing, transport, recreation and communications in particular are usually higher in urban areas compared with rural areas. In addition, urban areas usually have higher incomes, which affect spending patterns. This means that the NFNH to Food ratio is almost always higher in urban areas than in rural areas.

Table 7.3 provides data on food share of household expenditure for rural and urban areas for 11 developing countries (Anker, 2011a). Even though these data indicate food share and not NFNH share, they are still useful to illustrate how different rural and urban areas are in terms of spending patterns. Food share of household expenditure is higher in rural areas in all 11 developing countries in Table 7.3. The rural-urban difference for these countries is 20.6 percentage points on average. Food share is also lower in capital cities than in other urban areas.

Since the food share of household expenditure differs between metropolitan areas, other urban areas, and rural areas, the NFNH share of household expenditure should also differ by location within countries. Table 7.4 shows how the NFNH share of household expenditure varies for rural and urban areas of Kenya and Vietnam (see data for India in Table 7.2). The NFNH to Food ratio is higher in urban areas compared with rural areas in all three of these countries, 1.25 compared with 0.48 in Kenya, 1.21 compared with 0.74 in India, and 0.92 compared with 0.77 in Vietnam.

There are several important implications of the large rural-urban differences in household expenditure patterns illustrated above. 
Table 7.3 Food share of household expenditure for urban and rural areas, 11 developing countries

\begin{tabular}{lcccc}
\hline Country & National & Urban & Rural & Rural-urban \\
\hline Bangladesh & 57.1 & 44.5 & 60.5 & 16.0 \\
India & 52.7 & 42.0 & 54.0 & 12.0 \\
Kiribati & 46.0 & 42.0 & 50.0 & 8.0 \\
Nepal & 57.5 & 37.6 & 61.2 & 23.6 \\
Oman & 29.9 & $23.5^{\mathrm{a}}$ & 50.3 & 26.8 \\
Pakistan & 58.1 & 35.2 & 68.0 & 32.8 \\
Samoa & 50.8 & $40.7^{\mathrm{a}}$ & 53.7 & 13.0 \\
Solomon Islands & 52.9 & $34.3^{\mathrm{a}}$ & 62.3 & 28.0 \\
Tuvalu & 46.3 & $34.5^{\mathrm{a}}$ & 61.9 & 27.4 \\
Venezuela & 32.2 & 28.8 & 57.4 & 28.6 \\
Vietnam & 42.9 & 34.9 & 45.8 & 10.9 \\
Average & 47.9 & 36.2 & 56.8 & $20.6^{\mathrm{b}}$ \\
\hline
\end{tabular}

Notes:

a Food share for capital city only.

b Difference somewhat overstated, because food share for four countries was for the capital city, which tends to have a lower food share compared to other urban areas.

Sources: Anker (2011) based on CPI expenditure weights.

Table 7.4 Percentage distribution of household expenditure shares for food, housing and NFNH for rural and urban areas, Kenya and Vietnam

\begin{tabular}{lccccc}
\hline Expenditure group $^{\mathrm{a}}$ & \multicolumn{3}{c}{ Kenya } & & \multicolumn{2}{c}{ Vietnam } \\
\cline { 2 - 3 } \cline { 5 - 6 } & Rural & Urban & & Rural & Urban \\
\hline Food & 59.9 & 35.3 & & 51.2 & 43.0 \\
Housing & 11.4 & 20.3 & & $4.7^{\mathrm{b}}$ & $6.4^{\mathrm{b}}$ \\
Other & 28.7 & 44.0 & & 42.9 & 53.4 \\
NFNH to Food ratio & 0.48 & 1.25 & & 0.77 & 0.92 \\
\hline
\end{tabular}

Notes:

a Expenditures adjusted for our methodology.

b Reported housing expenditure unrealistically low in Vietnam, because cost or value of owner-occupied housing is excluded.

Sources: KNBS (2007), Vietnam Government (2012). 
- NFNH to Food ratio is almost always lower in rural areas than in urban areas in a country.

- Size of the difference in the NFNH to Food ratio between rural and urban areas varies considerably across countries.

- Household expenditure data for the area (e.g. rural, urban, or metropolitan urban) of a living wage study should be used whenever possible. Data for rural areas should be used for rural living wage estimates, and data for urban areas should be used for urban estimates.

- When only national household expenditure data are available, researchers should make every effort to obtain rural or urban data through special tabulations.

\subsection{Some NFNH Expenditures Unnecessary for Decent Living Standard}

It is important for a living wage to be seen as reasonable by workers, employers, governments and laypersons. For this reason, expenditures for goods or services that many people would feel are unnecessary for a living wage are sometimes excluded when estimating NFNH costs. Excluding expenses that are not needed for a decent living standard helps make it clear that a living wage estimate is frugal and reasonable. ${ }^{9}$

At the same time, we feel that the number of items excluded should be limited so as to avoid appearing petty, overly moralistic, or culturally insensitive. ${ }^{10}$ As American President Franklin D. Roosevelt (1944) said, 'Liberty requires opportunity to make a living - a living decent according to the standard of the time, a living that gives man not only enough to live by, but something to live for.' We recommend limiting unnecessary expenditures to tobacco, narcotics, 'excessive' alcohol consumption, and additional cost associated with owning and operating personal motor vehicles compared with exclusive use of passenger transport when passenger transport is considered acceptable for decency.

\section{PART III. HOW TO ESTIMATE NFNH COSTS}

The preliminary estimate of NFNH costs in our methodology is based in large part on household expenditures from a recent household expenditure survey. It is not based on normative standards. This means that there is a risk that insufficient funds could be included in NFNH for decency. This is especially likely in poor countries where many and sometimes a majority of people do not have decent health care, education, etc. To help correct for this possible problem, rapid assessment post checks are done for the two NFNH expenditures that are human rights (education and health 
care). NFNH costs are increased when indicated as being necessary based on rapid assessment post checks. Since there is considerable variability in how countries measure and classify household expenditures and this can significantly affect NFNH estimates, our methodology requires researchers to carefully inspect and adjust the available household expenditure data as needed so that they conform to how our living wage is estimated. This improves cross-country comparability and living wage estimates. It is worth noting that other common living wage and poverty line methodologies do not consider whether or not sufficient funds are included for nonfood expenses, nor do they look at how available household expenditure data are measured or classified.

\subsection{Four-step Approach to Estimate NFNH Costs}

A four-step approach is used to estimate NFNH costs for a living wage. The first step requires researchers to select appropriate household expenditure data from a secondary source - for rural or urban areas and percentile of the expenditure distribution that is felt to best reflect the expenditure pattern for a living wage. Step 2 adjusts the household expenditure data to be consistent with our methodology. Expenses considered to be unnecessary for a living wage are excluded and household expenditure data are adjusted to be consistent with how food, housing, and NFNH costs are estimated in our living wage methodology. Step 3 makes a preliminary estimate of NFNH costs for a living wage based on steps 1 and 2 by multiplying the adjusted NFNH to Food expenditure ratio by the cost of the living wage model diet. In step 4, rapid post checks are carried out for health care and education (and possibly transport), and adjustments are made to the preliminary NFNH estimate when necessary to ensure that sufficient funds are available for these.

\subsubsection{STEP 1: Select appropriate household expenditure data}

Because expenditure patterns are so different in rural and urban areas (see Section 7.7 above), data for rural areas should be used when estimating a living wage for a rural area and urban data should be used when estimating a living wage for an urban area. Every effort should be made to obtain special tabulations when data needed for a location and/or income percentile are not published.

Before using recent household expenditure data to estimate NFNH costs for a living wage, it is necessary to decide which part of the income distribution would best represent typical spending of workers who would earn a living wage. The 40th percentile is generally recommended for most developing countries. The 40th percentile household is poorer than 
the median (50th percentile) household and has less than average (mean) expenditure. It would be reasonable to use expenditures for the 50th percentile for countries with very high poverty rates, and the 30th percentile for some middle-income developing countries. For further discussion on this, see Section 7.5 above.

\subsubsection{What to do when household expenditure data are not available} by income level In some countries, data on household expenditure by expenditure group are available only for average (mean) household expenditures. But the pattern of household expenditure is known to differ by income, with NFNH higher for mean household expenditure (which is greatly affected by the spending of richer households because every dollar or rupee is counted equally in the calculation of mean expenditure) compared with expenditure of the median household. Analysis in Appendix 7.2 indicates that it is difficult to have hard and fast rules on how to adjust the NFNH to Food ratio when only mean expenditure data are available because there is a good deal of variation in this difference across countries. Despite this variability, making an approximate adjustment to the mean NFNH to Food ratio would be better than making no adjustment. So we suggest reducing the mean NFNH to Food ratio when necessary because of lack of data, by the following percentages: $20 \%$ for median, $25 \%$ for the 40 th percentile, and $30 \%$ for the 30 th percentile.

\subsubsection{STEP 2: Adjusting household expenditure data to conform to Anker methodology}

Other methodologies typically use household expenditure data without scrutiny. Adjustments are almost always necessary in our methodology. These adjustments are discussed in the remainder of this section. Table 7.5 is a worksheet that can be used to adjust the classification of NFNH expenditures found in secondary data so that they can be used in our methodology. Details about adjustments are discussed in subsequent sections. Table 7.6 provides an example.

\subsubsection{Adjusting NFNH for food eaten away from home Many people} eat meals away from home all around the world. Yet, our living wage methodology assumes that all meals are prepared at home, since food costs are estimated using a model diet. This means that it is necessary to take into consideration that meals away from home reduce the need for home cooked meals before using household expenditure data to estimate the NFNH to Food cost ratio. For example, if $6 \%$ of household expenditure in a country was spent for meals away from home and $50 \%$ of the cost of meals away from home was for services (such as cooking meals, washing dishes, and 
Table 7.5 Worksheet for calculating NFNH to Food ratio before post checks using secondary household expenditure data

\begin{tabular}{|c|c|c|c|c|}
\hline $\begin{array}{l}\text { Major } \\
\text { expenditure } \\
\text { group }\end{array}$ & $\begin{array}{l}\text { Sub-major } \\
\text { expenditure } \\
\text { group }\end{array}$ & $\begin{array}{l}\% \text { expenditure } \\
\text { in secondary } \\
\text { data }\end{array}$ & Adjustment explanation & $\begin{array}{l}\% \text { after } \\
\text { adjustment }\end{array}$ \\
\hline \multicolumn{5}{|l|}{ Food } \\
\hline & $\begin{array}{l}\text { Food \& } \\
\text { nonalcoholic } \\
\text { beverages }\end{array}$ & & $\begin{array}{l}\text { WHEN food away } \\
\text { is included in } \\
\text { restaurants and hotels } \\
\text { add part of food away } \\
\text { here }\end{array}$ & \\
\hline & $\begin{array}{l}\text { Alcohol (if } \\
\text { included here) }\end{array}$ & & $\begin{array}{l}\text { Put alcohol into the } \\
\text { alcohol \& tobacco } \\
\text { major group \& use } 0 \\
\text { here }\end{array}$ & 0 \\
\hline & $\begin{array}{l}\text { Tobacco (if } \\
\text { included here) }\end{array}$ & & $\begin{array}{l}\text { Exclude tobacco. } \\
\text { Use } 0 \text { here }\end{array}$ & 0 \\
\hline & $\begin{array}{l}\text { Meals away } \\
\quad \text { (if included } \\
\text { here) }\end{array}$ & & $\begin{array}{l}\text { Put part of meals } \\
\text { away into restaurants } \\
\text { \& subtract that part } \\
\text { here. }^{\text {a }}\end{array}$ & \\
\hline & $\begin{array}{l}\text { Cooking fuel } \\
\text { (if included } \\
\text { here) }\end{array}$ & & $\begin{array}{l}\text { Put into housing \& } \\
\text { use } 0 \text { here }\end{array}$ & 0 \\
\hline \multicolumn{5}{|l|}{ Total food } \\
\hline Housing & & & $\begin{array}{l}\text { Add cooking fuel } \% \\
\text { here WHEN cooking } \\
\text { fuel is included in food }\end{array}$ & \\
\hline \multicolumn{5}{|c|}{ Alcohol \& tobacco } \\
\hline & $\begin{array}{l}\text { Alcohol } \\
\quad \text { (if included } \\
\text { here) }\end{array}$ & & $\begin{array}{l}\text { (WHEN alcohol was } \\
\text { in food group) Add } \\
\text { alcohol here. Reduce if } \\
\text { excessive. }\end{array}$ & \\
\hline & $\begin{array}{l}\text { Tobacco } \\
\quad \text { (if included } \\
\text { here) }\end{array}$ & & Exclude & 0 \\
\hline $\begin{array}{l}\text { Restaurants } \\
\text { and hotels }\end{array}$ & & & $\begin{array}{l}\text { (WHEN food away } \\
\text { included in food group) } \\
\text { Add part here. }\end{array}$ & \\
\hline
\end{tabular}


Table 7.5 (continued)

\begin{tabular}{|c|c|c|c|c|}
\hline $\begin{array}{l}\text { Major } \\
\text { expenditure } \\
\text { group }\end{array}$ & $\begin{array}{l}\text { Sub-major } \\
\text { expenditure } \\
\text { group }\end{array}$ & $\begin{array}{l}\% \text { expenditure } \\
\text { in secondary } \\
\text { data }\end{array}$ & $\begin{array}{l}\text { Adjustment } \\
\text { explanation }\end{array}$ & $\begin{array}{l}\% \text { after } \\
\text { adjustment }\end{array}$ \\
\hline $\begin{array}{l}\text { Restaurants } \\
\text { and hotels }\end{array}$ & & & $\begin{array}{l}\text { (WHEN food away } \\
\text { included here) Put part } \\
\text { into food group \& } \\
\text { subtract that part here. }^{\text {a }}\end{array}$ & \\
\hline $\begin{array}{l}\text { Clothing and } \\
\text { footwear }\end{array}$ & & & None & \\
\hline $\begin{array}{l}\text { Household } \\
\text { contents and } \\
\text { appliances } \\
\end{array}$ & & & None & \\
\hline Health & & & None & \\
\hline Education & & & None & \\
\hline \multicolumn{5}{|l|}{ Transport } \\
\hline & $\begin{array}{c}\text { Private vehicle } \\
\text { purchases }\end{array}$ & & \multirow{2}{*}{$\begin{array}{l}\text { Subtract part of this } \\
\text { when workers expected } \\
\text { to exclusively use public } \\
\text { transport. }\end{array}$} & \\
\hline & $\begin{array}{c}\text { Private vehicle } \\
\text { operation }\end{array}$ & & & \\
\hline & $\begin{array}{l}\text { Passenger } \\
\text { transport }\end{array}$ & & None & \\
\hline Communication & & & None & \\
\hline $\begin{array}{l}\text { Recreation \& } \\
\text { culture }\end{array}$ & & & None & \\
\hline $\begin{array}{l}\text { Miscellaneous } \\
\text { goods \& } \\
\text { services }\end{array}$ & & & None & \\
\hline Total NFNH & & & & \\
\hline
\end{tabular}

Notes:

a Percentage of the cost of meals away from home for the food in these meals varies across countries, especially depending on whether meals are sold in fixed establishments or on street (base assumption is $50 \%$ of cost of meals away is for the food in these meals for most developing countries, $70 \%$ for Asian type street markets, and 30\% for developed countries).

b Additional expenses for owning and operating a private vehicle compared with exclusive use of passenger transport varies by country, especially whether motorbike or car is the norm (base assumption is $50 \%$ for developing countries). 
serving), other costs (e.g. cooking fuel, electricity, rent, dishes), and profit, then $3 \%$ (i.e. $50 \% \times 6 \%$ ) of household expenditure in this example would be for the food in these meals.

National statistical offices differ in how they classify food eaten away from home in their household expenditure statistics. While a majority of countries include food eaten away from home in its own expenditure group (called restaurants and hotels in COICOP), many countries include food eaten away from home within the food expenditure group. This means that how food eaten away from home is classified in national household expenditure data needs to be taken into consideration before the NFNH to Food ratio is estimated in our methodology.

When food eaten away from home is included in its own major expenditure group as in CIOCOP, reported food expenditure should be increased by the value of the food in meals away from home and expenditure for meals away from home should be reduced by the same value. Using the above example, $3 \%$ would be added to the reported percentage for food and 3\% should be subtracted from the reported percentage for NFNH.

When food eaten away from home is included in the food expenditure group (which occurs in around 22\% of countries according to Anker, 2011a), value of services and profit in meals away from home should be subtracted from the reported percentage for food and added to the reported percentage for NFNH. Using the above example, 3\% should be subtracted from the reported percentage for food and 3\% should be added to the reported percentage for NFNH.

We have conducted ad hoc inquiries in a number of countries to estimate the percentage of the cost of meals purchased away from home that is for the food in such meals. We bought meals from vendors frequented by workers and took these meals with us. We subsequently separated out all of the food items in these meals and weighed each food item. For example, a meal might consist of 10 grams of tomato, 20 grams of chicken, 100 grams of rice, and 20 grams of greens. We then estimated the cost of the meal if it had been prepared at home by multiplying the weight of each item in the meal by its price per gram in our local food market and added $5-10 \%$ for spices/condiments and fish or chicken stock depending on what was appropriate for a country. We have found that around $50 \%$ of the cost of meals eaten away from home was for the food in these meals in the Dominican Republic, Costa Rica, and South Africa. We found that around $70 \%$ of the cost of meals was for the food in street food meals in Vietnam, Cambodia, and China. We found that around $30 \%$ of the cost of meals away from home was for the food in these meals in the United States. Researchers should use a percentage for the cost of food in meals eaten away from home that is reasonable for their location. 
7.8.2.2 Adjusting for other expenditures included in food expenditure group It is common for national statistical offices to include items besides food in the food expenditure group. When this happens, it is necessary to reduce the reported percentage spent for food and increase the percentage for the appropriate expenditure group. Alcohol and tobacco are often included in the food expenditures group in household expenditure data. Cooking fuel is sometimes included in food expenditure. None of these items are included in a living wage model diet. When alcohol, tobacco or narcotics are included in the food group, this should be subtracted from food expenditure and added to NFNH expenditure. When cooking fuel is included in the food expenditure group, it should be subtracted from food expenditure and added to housing expenditure.

7.8.2.3 Adjusting for when workers expected to exclusively use passenger transport Transportation consists of three expenditure groups in COICOP: (i) purchase of personal vehicles, (ii) operation of personal vehicles, and (iii) passenger transport. When it is acceptable/decent in a location for workers earning a living wage to exclusively use passenger transportation, we recommend reducing the percentage spent for transport by the additional costs associated with owning and operating a personal vehicle compared with exclusive use of public transport. We typically assume that motorbikes/motor scooters (that are common in developing countries) are twice as expensive to own and operate as passenger transport - and we think that this is a reasonable assumption for most developing countries. ${ }^{11}$

The size of an adjustment for transport will be small in locations where relatively few workers own a private vehicle. This turned out to be the case in rural South Africa where households at the 30th and 40th percentile of the income distribution spend only around $1.0 \%$ for private vehicles according to secondary data. The adjustment was fairly large for the rural Dominican Republic where households in the lower half of the income distribution spend around $6 \%$ for private vehicles because many people own motorbikes.

\subsubsection{STEP 3: Preliminary estimate of NFNH costs}

The preliminary estimate of NFNH costs for a living wage is equal to the cost of the living wage model diet multiplied by the adjusted NFNH to Food ratio for the appropriate location and the appropriate part of the income distribution. 


\subsubsection{STEP 4: Post checks for health care and education (and possibly transport)}

The preliminary estimate of NFNH costs for a living wage from step 3 in our methodology is subject to post checks and possible adjustments to make sure that sufficient funds are available for health care and education, because they are considered human rights around the world. Post checks are also sometimes done for transport when this is a major expense. Post checks compare the amount implicitly included in the preliminary NFNH estimate for health care and education to rapid assessment estimates of typical costs for acceptable education and health care. NFNH is then increased when a rapid assessment indicates that there is a big difference. How to do rapid post checks is discussed in the next three chapters.

\subsection{Example of How to Estimate NFNH Costs: Hypothetical Example}

A hypothetical example is provided below to illustrate the steps involved in estimating NFNH costs. The hypothetical distribution of household expenditure data in this example is shown in Table 7.6. In addition, we assume that the poverty rate is $35 \%$.

\subsubsection{STEP 1: Decide which part of the income distribution is appropriate to use to estimate NFNH costs}

Since the poverty rate is $35 \%$, expenditure data for households at the 40th percentile of the expenditure distribution from a recent household expenditure survey was used to estimate NFNH costs. Such households in this example spent $6.0 \%$ of household expenditure for owning and operating private vehicles, $8.0 \%$ for passenger transport, $1.7 \%$ for alcohol, $1.0 \%$ for tobacco, and $4.8 \%$ for food eaten away from home.

\subsubsection{STEP 2: Adjust household expenditure data as necessary}

a. Exclude unnecessary expenses

We considered tobacco unnecessary and so excluded it. We did not exclude alcohol since $1.7 \%$ of household expenditures for alcohol was not felt to be excessive. Note that the percentage for alcohol was moved from the food group into NFNH.

b. Adjust food expenditure group and restaurant expenditure group for food eaten away from home

We added half of the expenditure of the 'restaurants expenditure group' to the 'food expenditure group' $(2.4 \%)$, and subtracted this same percentage $(2.4 \%)$ from the restaurant expenditure group. We used half based on ad hoc inquiries we have done in developing countries that indicate that it is typical that around half of the cost of meals 
Table 7.6 NFNH to Food ratio based on secondary data from household expenditure survey before and after adjustments, hypothetical example

\begin{tabular}{|c|c|c|c|c|}
\hline $\begin{array}{l}\text { Major } \\
\text { expenditure } \\
\text { group }\end{array}$ & $\begin{array}{l}\text { Sub-major } \\
\text { expenditure } \\
\text { group }\end{array}$ & $\begin{array}{c}\% \text { expenditure } \\
\text { in secondary } \\
\text { data }\end{array}$ & Adjustments & $\begin{array}{c}\% \text { after } \\
\text { adjustment }\end{array}$ \\
\hline \multirow[t]{5}{*}{ Food } & Total & 37.6 & $\begin{array}{c}\text { Alcohol and tobacco } \\
\text { subtracted \& } 1 / 2 \text { of } \\
\text { restaurants added }\end{array}$ & 37.3 \\
\hline & $\begin{array}{l}\text { Food \& } \\
\text { nonalcoholic } \\
\text { beverages }\end{array}$ & 34.9 & & 34.9 \\
\hline & Alcohol & 1.7 & $\begin{array}{l}\text { Put into alcohol \& } \\
\text { tobacco major group }\end{array}$ & 0 \\
\hline & Tobacco & 1.0 & Excluded & 0 \\
\hline & $\begin{array}{l}\text { Meals away } \\
\text { from home }\end{array}$ & 0 & $\begin{array}{l}\text { Food part of meals } \\
\text { away added }\end{array}$ & 2.4 \\
\hline Housing & Total & 16.0 & & 16.0 \\
\hline NFNH & Total & 46.4 & & 42.7 \\
\hline \multirow[t]{3}{*}{$\begin{array}{r}\text { Alcohol \& } \\
\text { tobacco }\end{array}$} & & 0 & & \\
\hline & Alcohol & 0 & Added alcohol here & 1.7 \\
\hline & Tobacco & 0 & Excluded & 0 \\
\hline $\begin{array}{l}\text { Restaurants } \\
\text { and hotels }\end{array}$ & & 4.8 & $\begin{array}{l}\text { Subtracted } 2.4(1 / 2 \text { of } \\
4.8 \text { and added it to } \\
\text { food) }\end{array}$ & $4.8-2.4=2.4$ \\
\hline $\begin{array}{l}\text { Clothing and } \\
\text { footwear }\end{array}$ & & 4.7 & None & 4.7 \\
\hline $\begin{array}{l}\text { Household } \\
\text { contents and } \\
\text { appliances }\end{array}$ & & 5.2 & None & 5.2 \\
\hline Health & & 5.5 & None & 5.5 \\
\hline Education & & 2.4 & None & 2.4 \\
\hline \multirow[t]{3}{*}{ Transport } & & 14.0 & & 11.0 \\
\hline & $\begin{array}{l}\text { Private } \\
\text { vehicle } \\
\text { purchases }\end{array}$ & 3.0 & \multirow{2}{*}{$\begin{array}{l}\text { Subtracted } 3.0(1 / 2 \text { of } \\
6.0 \text { as assumed private } \\
\text { vehicles were twice as } \\
\text { expensive as passenger } \\
\text { transport) }\end{array}$} & 1.5 \\
\hline & $\begin{array}{l}\text { Private } \\
\text { vehicle } \\
\text { operation }\end{array}$ & 3.0 & & 1.5 \\
\hline
\end{tabular}


Table 7.6 (continued)

\begin{tabular}{|c|c|c|c|c|}
\hline $\begin{array}{l}\text { Major } \\
\text { expenditure } \\
\text { group }\end{array}$ & $\begin{array}{l}\text { Sub-major } \\
\text { expenditure } \\
\text { group }\end{array}$ & $\begin{array}{c}\% \text { expenditure } \\
\text { in secondary } \\
\text { data }\end{array}$ & Adjustments & $\begin{array}{c}\% \text { after } \\
\text { adjustment }\end{array}$ \\
\hline & $\begin{array}{l}\text { Passenger } \\
\text { transport }\end{array}$ & 8.0 & None & 8.0 \\
\hline Communication & & 3.8 & None & 3.8 \\
\hline $\begin{array}{l}\text { Recreation \& } \\
\text { culture }\end{array}$ & & 2.2 & None & 2.2 \\
\hline $\begin{array}{l}\text { Miscellaneous } \\
\text { goods \& } \\
\text { services }\end{array}$ & & 3.8 & None & 3.8 \\
\hline $\begin{array}{l}\text { NFNH/FOOD } \\
\text { ratio }\end{array}$ & & $\begin{array}{c}1.23 \\
(46.4 / 37.6)\end{array}$ & & $\begin{array}{c}1.14 \\
(42.7 / 37.3)\end{array}$ \\
\hline
\end{tabular}

away from home is for the food in these meals and around half is for profit and services such as food preparation, cooking, cleaning and serving.

c. Reduce transport expenditure by additional costs associated with owning and operating a private vehicle compared with exclusive use of passenger transport

According to the household expenditure data, $6.0 \%$ of household expenditure was for owning and operating private vehicles, while $8.0 \%$ was for passenger transport. We concluded based on discussions with workers and key informants that it was acceptable for decency for workers earning a living wage to exclusively use passenger transportation. We assumed that owning and operating a private vehicle was twice as expensive as using passenger transport. Therefore, we subtracted $3.0 \%$ (half of the $6.0 \%$ of household expense for private vehicles) from transport. We were left with a total of $11.0 \%$ for transport (i.e. $8.0 \%+1 / 2$ of $6.0 \%$ ).

\subsubsection{STEP 3: Calculate adjusted NFNH to Food cost ratio}

The adjusted NFNH to adjusted Food ratio was 1.14 (i.e. 42.7/37.3). Note that the unadjusted ratio was 1.23 (i.e. 46.4/37.6).

\subsubsection{STEP 4: Calculate post check adjustments for health care and education}

a. Calculate preliminary NFNH estimate by multiplying NFNH to Food ratio from step 3 by the cost of the living wage model diet 
The cost of the living wage model diet in this example was 9,885 per month for a reference size family of four. Therefore, the preliminary estimate of NFNH costs was 11,269 per month (i.e. 9,885 × 1.14).

b, Compare post check estimates of costs of decent health care and education for children to amounts included for these in preliminary NFNH estimate, and increase preliminary NFNH estimate if necessary

In this example, approximately 1,452 was included in the preliminary NFNH estimate for health care $(11,269 \times 5.5 / 42.7)$. The rapid health care post check found that 1,510 was needed for health care. No adjustment was made for health care, because the rapid post check amount was similar to the preliminary estimate. For education, 633 was included in the preliminary NFNH estimate $(11,269 \times 2.4 / 42.7)$. The rapid post check found that 950 was needed for education of children in the reference family through secondary school. For this reason, NFNH was increased by 300 per month for education. The need for additional funds for education made sense because secondary enrollment rates were low in this example, which meant that household expenditure statistics did not adequately reflect the required cost of educating all children through secondary school.

\section{NOTES}

1. Under certain circumstances a post check is also done for transportation, when this is a large expense.

2. Countries are often slow to adopt latest COICOP. Also, many countries adjust COICOP to better measure welfare and behavior rather than inflation, which is the main raison d'être of COICOP.

3. Anker (2011a) found that $43 \%$ of 207 countries and territories included alcohol and tobacco in their food expenditure group in their CPI expenditure weights.

4. Anker (2011a) found that $22 \%$ of 207 countries and territories included food eaten away from home in the food expenditure group in their CPI expenditure weights.

5. For developing countries, a single large 'other' expenditure group (i.e. all non-food expenses) is typically used along with food expenses to estimate living wages and poverty lines based on Engel's Law (Anker, 2011a). High-income countries such as United States, Canada and United Kingdom, with considerable secondary data series, typically use around 5 or 6 expense groups including an 'other' group with typically around $20 \%$ of all expenses.

6. 'An elasticity measures sensitivity of one variable to another. Specifically, it is a number that tells us the percentage change that will occur in one variable in response to a 1 percent increase in another variable' (Pindyck and Rubinfield, 2012). For example if income rose by $10 \%$ and the income elasticity for food was 0.60 , food expenditure would increase by $6 \%$.

7. According to Engel's law, 'The poorer is a family, the greater is the proportion of the total outgo [family expenditures] which must be used for food' (Engel quoted in Zimmerman, 1932).

8. The income elasticity of food expenditure ranges from 0.24 for high income countries to 0.78 for low income countries according to Anker (2011a). 
9. This is similar to excluding cakes, candy and soda from a living wage model diet.

10. It is possible to go too far in excluding items in our opinion. For example, the Canadian Government's Market Basket Measure (MBM), which is used as a poverty line for Canada excludes alcohol, tobacco, eating out, pets, hotels, gambling, and jewelry (Human Resources Development Canada, 2003). The MIT living wage calculator for the United States excludes these items plus toys, hobbies, movies and TV (Nadeau, 2014).

11. We found that owning and operating a private vehicle is around three times more expensive than passenger transport in urban South Africa because cars predominated among private vehicles in South Africa.

12. A detailed description of COICOP is in Annex 2 of the ILO Consumer Price Index Manual (ILO et al., 2004). 


\section{APPENDIX 7.1 COICOP (CLASSIFICATION OF INDIVIDUAL CONSUMPTION ACCORDING TO PURPOSE): INTERNATIONALLY ACCEPTED CLASSIFICATION FOR HOUSEHOLD EXPENDITURES ${ }^{12}$}

- $\underline{01}-$ Food and non-alcoholic beverages

- 01.1 - Food

- 01.2 - Non-alcoholic beverages

- $\underline{02}$ - Alcoholic beverages, tobacco and narcotics

- 02.1 - Alcoholic beverages

- $\underline{02.2}$ - Tobacco

- $\underline{02.3}$ - Narcotics

- $\underline{03}$ - Clothing and footwear

- $\underline{03.1}$ - Clothing

- $\underline{03.2}$ - Footwear

- 04 - Housing, water, electricity, gas and other fuels

- 04.1 - Actual rentals for housing

- 04.2 - Imputed rentals for housing

- 04.3 - Maintenance and repair of the dwelling

- $\quad 04.4$ - Water supply and miscellaneous services relating to the dwelling

- $\quad 04.5$ - Electricity, gas and other fuels

- $\underline{05}$-Furnishings, household equipment and routine household maintenance

- 05.1 -Furniture and furnishings, carpets and other floor coverings

- $\underline{05.2}$ - Household textiles

- 05.3 - Household appliances

- 05.4 - Glassware, tableware and household utensils

- $\quad 05.5$ - Tools and equipment for house and garden

- $\quad 05.6$ - Goods and services for routine household maintenance

- $\underline{06}-$ Health

- $\underline{06.1}$ - Medical products, appliances and equipment

- 06.2 - Outpatient services

- $\underline{06.3}$ - Hospital services

- $\underline{07}$ - Transport

- 07.1 - Purchase of vehicles

- $\underline{07.2}$ - Operation of personal transport equipment

- $\underline{07.3}$ - Transport services

- 08 -Communication 
- $\underline{08.1}$ - Postal services

- $\underline{08.2}$ - Telephone and telefax equipment

- $\underline{08.3}$ - Telephone and telefax services

- 09 - Recreation and culture

- 09.1 - Audio-visual, photographic and information processing equipment

- $\underline{09.2}$ - Other major durables for recreation and culture

- $\underline{09.3}$ - Other recreational items and equipment, gardens and pets

- $\underline{09.4}$ - Recreational and cultural services

- $\underline{09.5}$ - Newspapers, books and stationery

- $\underline{09.6}$ - Package holidays

- $10-$ Education

- 10.1 - Pre-primary and primary education

- $\underline{10.2}$ - Secondary education

- $\underline{10.3}$ - Post-secondary non-tertiary education

- $\underline{10.4}-$ Tertiary education

- 10.5 - Education not definable by level

- 11 - Restaurants and hotels

- $\underline{11.1}$ - Catering services

- 11.2 - Accommodation services

- $12-$ Miscellaneous goods and services

- $\underline{12.1}$ - Personal care

- $\underline{12.2}-$ Prostitution

- $\underline{12.3}$ - Personal effects not elsewhere classified

- $\underline{12.4}$ - Social protection

- 12.5 - Insurance

- $\underline{12.6}$ - Financial services not elsewhere classified

- $\underline{12.7}$ - Other services not elsewhere classified 


\section{APPENDIX 7.2 NEED TO ADJUST NFNH TO FOOD RATIO WHEN ONLY AVERAGE (MEAN) HOUSEHOLD EXPENDITURE DATA ARE AVAILABLE}

As shown and discussed in Section 7.5, the NFNH to Food ratio is higher when it is based on average household expenditure data than when it is based on expenditures of the median household or households at the 30th or 40th percentile of the household expenditure distribution. This presents a problem when the only published household expenditure data are for average household expenditures, because in this situation the NFNH to Food ratio estimated would be too high. The first thing a researcher should do in this situation is to make every effort to get a special tabulation of household expenditures by income decile or quintile. We were able to do this, for example, for rural Dominican Republic and Phnom Penh, Cambodia.

This appendix addresses the issue of what to do when after serious efforts have been made, a researcher only has data on mean household expenditure, and whether it is possible to develop guidelines for this situation. To address this, we put together data on the NFNH to Food ratio for the median household and mean household expenditure for: (i) 15 developing countries and territories from an ILO household income and expenditure survey database, and (ii) 5 developing countries where we had done living wage studies and so were able to adjust the household expenditure data to be consistent with how we estimate the NFNH to Food ratio in our methodology.

The NFNH to Food ratio was 25\% lower on average (median) for the 15 developing countries and territories in the ILO database when this ratio was based on median household expenditure compared with when it was based on mean household expenditure. It was always lower for median expenditure than for mean expenditure, but there was considerable variability across countries as differences ranged from $9 \%$ to $40 \%$.

Table 7A.1 examines the same issue of how the NFNH to Food ratio changes with household income for five developing countries where we were able to adjust the expenditure data to be consistent with our methodology. The NFNH to Food ratio was always higher when based on mean household expenditure than when based on expenditure of median household (and the NFNH share of household expenditure uniformly increased with household income in all five countries). This ratio was around $17 \%$ lower on average (median) when based on the median household expenditure compared to when the ratio was based on the mean household expenditure. As with countries in the ILO database, there was 
Table 7A.1 Percentage decrease in NFNH to Food ratio when based on mean household expenditure compared with when based on expenditure of households at 50th, 40th, and 30th percentile of household expenditure distribution using Anker methodology adjustments, five developing countries

\begin{tabular}{lccccc}
\hline Country & $\begin{array}{c}\text { Mean to } \\
\text { median }\end{array}$ & $\begin{array}{c}\text { Mean to } \\
40 \text { th } \%\end{array}$ & $\begin{array}{c}\text { Mean to } \\
30 \text { th } \%\end{array}$ & $\begin{array}{c}\text { Median } \\
\text { to 40th } \%\end{array}$ & $\begin{array}{c}40 \text { th } \% \text { to } \\
30 \text { th } \%\end{array}$ \\
\hline $\begin{array}{l}\text { Dominican Republic } \\
\quad \text { (national) }\end{array}$ & 25 & 35 & 43 & 13 & 12 \\
South Africa (primary urban) & 67 & 69 & 70 & 4 & 4 \\
Vietnam (national) & 11 & 16 & 20 & 5 & 4 \\
Cambodia (Phnom Penh) & 4 & 14 & 24 & 10 & 11 \\
India (urban Maharashtra) & 19 & 27 & 33 & 10 & 8 \\
India (rural Maharashtra) & 14 & 19 & 22 & 6 & 3 \\
Total (average) & $23 \%$ & $30 \%$ & $35 \%$ & $8 \%$ & $7 \%$ \\
Total (median) & $16 \%$ & $23 \%$ & $29 \%$ & $8 \%$ & $6 \%$ \\
\hline
\end{tabular}

Sources: Anker, R and Anker, M (2015, unpublished) for Vietnam, Cambodia and India. Anker and Anker (2014a) for Dominican Republic. Anker and Anker (2013) for South Africa.

considerable variation in this difference across countries as it ranged from $4 \%$ to $67 \%$. At the same time, the decrease in the NFNH to Food ratio was much smaller and much less variable as you go from the median to the 40th percentile and from the 40th to the 30th percentile of the household expenditure distribution; the ratio is around 7\% lower on average between these deciles.

Implications of the above analyses are:

- When only average (mean) household expenditure data are published, every effort should be made to obtain household expenditure data by income decile or quintile including through special tabulations.

- When it is not possible to obtain these data after serious efforts, it is still necessary to adjust the mean NFNH to Food ratio downward. Although there is considerable variation across countries in how much lower the NFNH to Food ratio is for households at the 30th to 50th percentiles of the household income distribution compared to this ratio when based on mean household expenditures, an adjustment of somewhere around $20 \%$ for median household, around $25 \%$ for the 40 th percentile household, and around $30 \%$ for the 30 th 
percentile household seem reasonable percentages to use. While it needs to be kept in mind that these percentages are very much only typical differences that may not be appropriate for specific countries, some adjustment is needed. 